\title{
Mykert-Sanzheevka Field of Polycomponent Ores (Pb, Zn, Ag, Au, PGE): Geologic-Substance Characteristics and Formation Features of Ore-Forming System
}

\section{Alexander Vasilyevich Tatarinov, Lyubov Ilyinichna Yalovik, Anatoly Georgievich Mironov, Victor Fedorovich Posokhov}

Geological Institute, Siberian Branch, Russian Academy of Sciences, Ulan-Ude, Russia

Email: tatarinov_42@mail.ru

How to cite this paper: Tatarinov, A.V., Yalovik, L.I., Mironov, A.G. and Posokhov, V.F. (2020) Mykert-Sanzheevka Field of Polycomponent Ores ( $\mathrm{Pb}, \mathrm{Zn}, \mathrm{Ag}, \mathrm{Au}, \mathrm{PGE})$ : Geologic-Substance Characteristics and Formation Features of Ore-Forming System. Geomaterials, 10, 1-23.

https://doi.org/10.4236/gm.2020.101001

Received: December 13, 2019

Accepted: January 28, 2020

Published: January 31, 2020

Copyright $\odot 2020$ by author(s) and Scientific Research Publishing Inc. This work is licensed under the Creative Commons Attribution International License (CC BY 4.0).

http://creativecommons.org/licenses/by/4.0/

c) (i) Open Access

\begin{abstract}
The new results of geologic-structural, petrographic and mineralogicgeochemical researches of Mykert-Sanzheevka ore field-the Uda-Vitim mineragenic zone South-West ending of West Transbaikalia are given. Its main ore-controlling structure, represented by losange, consisting of rhombohedral and tetrahedral blocks-duplexes mosaic clusters, which are separated by narrow tectonic sutures, is specified. It is clarified that polycomponent ores clusters are confined with these small-block sutures, made by subvolcanic dykes of shoshonite-latite volcano-plutonic association (233 - 188 million years), apodyke dynamometamorphites (breccias, cataclasite, mylonites) and also mechanometasomatites. Four stages of the dynamometamorphites formation characterized by different species compositions of ore minerals appeared as a result of mechanochemical reactions are determined. A carbonyl model of mineral microaggregates formation with films containing noble metal nanoparticles is proposed. Ore-forming system features of Mykert-Sanzheevka field are considered.
\end{abstract}

\section{Keywords}

Polycomponent Ores, Dynamometamorphism, Mechanometasomatites,

Noble Metals, Microaggregates, Nanophases, Trace Minerals, Ore-Forming System, Carbonyl Compounds, Geochemical Microanomalies

\section{Introduction}

Over the past 10 - 15 years, the authors of this article had carried out a minera- 
logical and geochemical study of the ore mineralization on a number of known gold and polymetals $(\mathrm{Pb}, \mathrm{Zn})$ deposits in the Baikal region, located within the Sayan-Baikal and Mongol-Okhotsk orogenic belts (Zun-Kholba, Baley, Irokinda, Kholodniy, Dovatka, etc.). The result of these researches was the identification and prediction of polycomponent noble-metal clusters ( $\mathrm{Au}, \mathrm{Ag}, \mathrm{Pt}, \mathrm{Pd})$ and noble-metal-polymetallic $(\mathrm{Pb}, \mathrm{Zn}, \mathrm{Ag}, \mathrm{Au}, \mathrm{Pt}, \mathrm{Ru})$ ores in many ore fields, and in Mykert-Sanzheevka too [1]-[6]. Very high concentrations of $\mathrm{Pt}$ and $\mathrm{Ru}$ in noble-polymetallic ores are identified in Sanzheevka, Mykert, Dovatka, Tarbagatay fields and occurrences by variety of modern chemical analytical methods (microprobing neutron activation, test tube, atomic absorption, $\mathrm{x}$-ray fluorescence using synchronous radiation, atomic emission). Small Mykert field of Sanzheevka mineral occurrence and Big Mykert form a single ore field (Figure 1). It should be noted that all attempts to find and diagnose the mineral phases of platinum group elements in all studied deposits by using the JXA-8100 microprobe and the LEO 1430 VP electron microscope were unsuccessful. The absence of PGE microphases allowed us to conclude that they are concentrated in an invisible form, most likely in the form of cluster compounds (nanoparticles) in sulfides which consist of PGE atoms groups surrounded by a dense layer of ligands (atoms $\mathrm{H}, \mathrm{Cl}, \mathrm{C}$, $\mathrm{S}$, etc.).

In the article the research results of noble-metal-polymetallic mineralization of Mykert-Sanzheevka ore field are presented. They concern poorly investigated the problem of its genesis based on the author's new mineralogic and geochemical obtained data, additional information on lithologic-petrographic and structural-geological peculiarities of the Sanzheevka mineral occurrence and Small

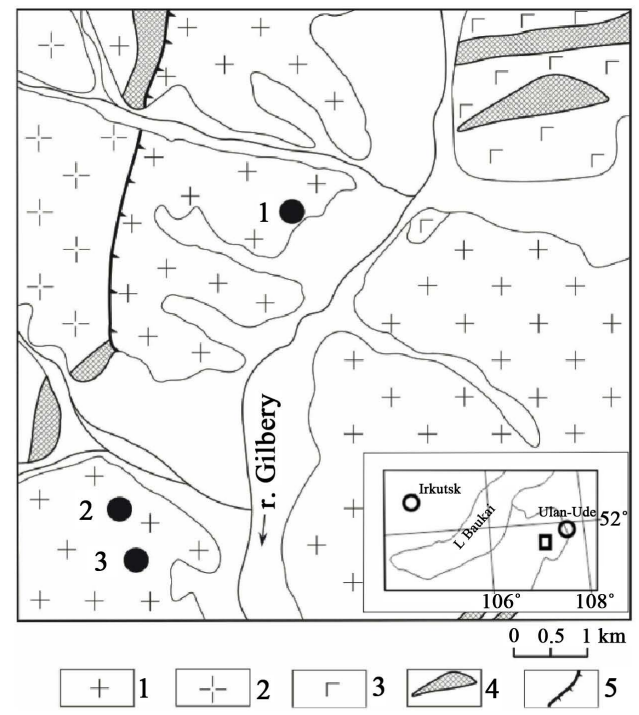

1 - Bichura complex granitoids; 2 - Barguzin complex granitoids; 3 -Ikat complex gabbroids of the Riphean age; 4 - crushed and fractured areas of rocks - kakirites; 5 - possible thrusts. White field loose Quaternary sediments. White field-the loose Prize sediments, geological map overview diagram depicted in the form of a rectangle.

Figure 1. Geological sites scheme of Mykert-Sanzheevka ore field (by A. A. Karvainov et al., 1979). Filled circles-ore sites (1-Big Mykert, 2-Small Mykert, 3-Sanzheevka). 
Mykert deposits. Early publications assumed the usual hydrothermal genesis of polycomponent ores [1] [2], without discussing the mechanisms of ore genesis and components sources. From the past researches vision field, the question of ore formation processes linkage with tectonic-metamorphic transformations of host rocks fell out. We considered it recent time on the example of polycomponent noble-metal ores in Irokinda and Irba deposits to which as well as to Mykert-Sanzheevka ore field, platinoids high contents with outstanding mineral occurrence forms are inherent [4] [6]. The authors of the article proposed the deformational formation mechanism of noble metal-polymetallic ores mineral associations. Particular attention is paid to the genesis problem of so-called "oxidation zones of weathering crusts" with noble metal mineralization [7] [8], the originality of which does not fit into traditional ideas, but the prospects for high productivity are highly appreciated.

\section{Research Method}

The researches complex, first of all, considering the solution of those questions which are today the most poorly studied, debatable, or genetic constructions, causing doubts in its reliability, was attracted. In addition, it was aimed to obtain additional data on ore mineralization, opened with ditches and clearing, which were passed in the last 10 - 15 years by private geological organizations.

This complex included the usual standard geological and structural observations, mapping of new ore deposits uncovered by surface mining, petrographic and mineralogical-geochemical study of rock and ore samples.

Special attention was paid to the identification of carbonaceous substance and ore microaggregates micro-inclusions, first discovered in the polished sections on the ore microscope. Then the most interesting portions, polished sections fragments, containing microaggregates of poorly diagnosed ore and non-metallic mineral phases, colloidal formations (gel minerals by [9]) were investigated on microanalyzer JXA-8100, Jed Ltd. firm, equipped with three wave spectrometers and energy dispersive prefix Link Pentafet, and/or electron microscope LEO 1430 VP with energy dispersive spectrometer INCA Energy 350.

The results of the chemical elements contents, obtained using these devices at particular points of microaggregates were calculated on the normative mineral compositions.

In determining the most probable chemical compositions and forms of platinoids nanoparticles occurrence, as well as $\mathrm{Ag}$ and $\mathrm{Au}$, data on the concentration and distribution of various elements were widely used, which were recorded on the scanograms of their characteristic radiation. On this basis, the characteristic of geochemical microfields was made, with the allocation of anomalous among them. At the qualitative level, the correlation between ore elements and fluid components (C, S, F, Cl) in anomalous geochemical microfields was estimated.

Chemical-spectral methods and $\mathrm{x}$-ray fluorescence analysis were used to study the ore-rock complex. Its age was determined by rubidium-strontium iso- 
tope-geochemical method.

\section{Geologic-Mineragenic Characteristics of the Ore Field}

According to geological surveys and prospecting of PGO "Buryatgeology", a large part of the ore field area is composed of Bichura complex syenites and diorites of middle Paleozoic with Mesozoic diorite porphyrites dykes, microdiorites, diabases. Outside, there are widespread bodies of Ikat complex.Neoproterozoic gabbros.

On Paleozoic granitoids distribution area of Mykert-Sanzheevka ore field, in addition to the mentioned ones there are known small outcrops of amphibolites, Itantsa suite crystallo-slates, dating from the Riphean (the Neoproterozoic). In eluvial-diluvial formations, coarse fragments and boulders of intensely cataclastic scarnoids and serpentinites are observed.

Noted rocks of ultramafic-mafic association, including the Itantsa suite metabasites-there is a characteristic peculiatity of Selenga-Vitim Greenstone belt [5], composing the Precambrian crystalline basement of Dzhida-Vitim polymetallic zone [1].

The whole rocks complex that form Mykert-Sanzheevka ore field, rapidly deployed.

Ore field is located at the intersection of the Upper Orongoy and Gilbery zones of side faults bounding the Mesozoic Upper Orongoy and Ivolga depression. The ore field occupies a portion between these depressions like a small horst.

Mykert-Sanzheevka ore field area is a part of the West Transbaikalia sector of the Mongol-Transbaikalia rift zone [10], represented by volcanogenic-plutonic structure, with the age of its composing rocks (trachybasalts, volcanic trachybasalt-comendite association, arrays of alkali granites and syenites) 233 - 188 million years.

In the 70 - 90-ies of XX century on the area of the ore field (Figure 1) the exploration works on the silver were purposefully carried out. The result was the discovery of one Small Mykert field and two mineral occurrences of silver (Big Mykert and Sanzheevka). Ag total forecast resources for the three objects identified by the exploration works, made by Buryat geological department by 1988 , were estimated at $2000 \mathrm{t}$. Mineragenic capacity of platinum group elements was calculated in the amount of $25 \mathrm{t}$. Au, $\mathrm{Pb}, \mathrm{Zn}, \mathrm{Cu}$ as the accompanying components, due to the small their extent, in the forecast resource estimations were not taken into account.

Presently, it is possible to state a very weak search knowledge of MykertSanzheevka field as the area object with complex ores.

The noble metal-polymetallic ore formation type deposits (Novo-Shirokinsk, Bystrinsk, etc.) are known in East Transbaikalia. Their formation is associated with the functioning of latite ore magmatic systems of Jurassic-Cretaceous time (192 - 196 million years) [11] [12] [13]. In contrast to the Mykert-Sanzheevka ore field, the dominant ore component of these deposits is gold, not silver, based 
on the results of exploration works.

\section{Substance Composition of Ore-Bearing Rocks}

Ore-bearing rocks of Mykert-Sanzheevka ore field are presented by shoshonite-latite volcano-plutonic association, which unites a plutonic series (gabbro, monzonite, syenites, subalkalic diorites) and mainly subvolcanic dyke series composed of species visually related by geologists practitioners to the diabase, the diabase and diorite porphyrites. At the same time, ore mineralization is localized in the dynamometamorphic complex resulting from two-three time tectonic-metamorphic transformations of shoshonite-latite association rocks.

As a part of the latter one, in various degrees, dynamometamorphic transformed petrotypes form a group: syenites, diorites mentioned above subvolcanic dyke rocks. They are presented by a number of petrochemical rocks of various alkalinity (Table 1): tephrite, trachybasalt and trachyandesitebasalt, alkaline syenite (trachyte).

Table 1. The chemical composition of Mykert-Sanzheevka field ore-bearing rocks.

\begin{tabular}{|c|c|c|c|c|c|c|c|c|}
\hline Components & 1 & 2 & 3 & 4 & 5 & 6 & 7 & 8 \\
\hline $\mathrm{SiO}_{2}$ & 47.12 & 50.29 & 50.32 & 49.96 & 53.20 & 51.96 & 52.68 & 62.70 \\
\hline $\mathrm{TiO}_{2}$ & 1.64 & 2.10 & 1.51 & 1.43 & 0.99 & 1.01 & 1.10 & 1.07 \\
\hline $\mathrm{Al}_{2} \mathrm{O}_{3}$ & 16.41 & 14.37 & 17.74 & 17.73 & 18.06 & 21.94 & 22.34 & 18.15 \\
\hline $\mathrm{Fe}_{2} \mathrm{O}_{3}$ & 8.85 & 7.28 & 5.23 & 5.05 & 3.94 & 4.01 & 4.17 & 2.49 \\
\hline $\mathrm{FeO}$ & 4.24 & 5.91 & 5.16 & 5.47 & 4.62 & 10.03 & 8.98 & 0.73 \\
\hline $\mathrm{MnO}$ & 0.24 & 0.23 & 0.19 & 0.20 & 0.18 & 0.13 & 0.013 & 0.14 \\
\hline $\mathrm{MgO}$ & 3.53 & 4.47 & 4.16 & 4.05 & 6.98 & 3.04 & 3.18 & 1.05 \\
\hline $\mathrm{CaO}$ & 8.22 & 8.50 & 8.20 & 8.68 & 5.98 & 1.64 & 1.42 & 1.81 \\
\hline $\mathrm{Na}_{2} \mathrm{O}$ & 5.45 & 3.72 & 4.05 & 4.03 & 3.71 & 0.55 & 0.13 & 5.28 \\
\hline $\mathrm{K}_{2} \mathrm{O}$ & 2.67 & 2.00 & 2.50 & 2.40 & 2.10 & 4.95 & 5.41 & 6.32 \\
\hline $\mathrm{P}_{2} \mathrm{O}_{5}$ & 1.63 & 1.20 & 0.94 & 1.00 & 0.24 & 0.74 & 0.46 & 0.26 \\
\hline $\mathrm{CO}_{2}$ & 4.62 & 0.66 & 1.10 & 1.54 & 1.54 & 0.44 & 0.66 & 0.44 \\
\hline $\mathrm{F}$ & 0.56 & 0.09 & 0.15 & 0.11 & 0.04 & 0.25 & 0.19 & 0.07 \\
\hline S & 0.13 & 0.04 & 0.13 & 0.12 & 0.05 & 0.04 & 0.16 & - \\
\hline $\mathrm{Cl}$ & 0.018 & 0.029 & 0.035 & 0.050 & 0.008 & 0.005 & 0.002 & - \\
\hline $\mathrm{Pb}$ & 6500 & 150 & 100 & 60 & 200 & 5200 & 1500 & 69 \\
\hline $\mathrm{Zn}$ & 168 & 110 & 84 & 110 & 63 & 4368 & 4313 & 1740 \\
\hline $\mathrm{Cu}$ & 21 & 33 & 20 & 20 & 39 & 123 & 63 & H.O \\
\hline $\mathrm{V}$ & 154 & 269 & 232 & 221 & 174 & 205 & 201 & H.O \\
\hline $\mathrm{Cr}$ & 18 & 21 & 17 & 16 & 89 & 42 & 50 & H.O \\
\hline Co & 22 & 27 & 23 & 25 & 25 & 23 & 24 & н.о \\
\hline $\mathrm{Ni}$ & 15 & 24 & 14 & 13 & 62 & 19 & 22 & H.O \\
\hline
\end{tabular}

Note: Elements oxides are calculated to dry residue (wt\%). $\mathrm{CO}_{2}, \mathrm{~F}, \mathrm{~S}, \mathrm{Cl}-\mathrm{wt} \%$, and ore elements-g/t, H.o-contents were not determined, “-”-not found. 1-8-petrochemical types of rocks on the TAS diagram (1-tephrite; 2 - 4-trachybasalt; 5 - 7-trachyandesatobasalt; 8-alkaline trachyte). Analysis of oksides, of $\mathrm{F}$ and $\mathrm{S}$ conducted laboratory of instrumental methods of analysis of GIN SO RAN Group (B.b. Lygdenovoj, etc.); The cntent of $\mathrm{Cl}$ and ore elements X-ray-fluorescent analysis VPA-90 B.i. B.J. Zhalsaraevym (GIN SO RAN). 
Below we give brief mineral-petrographic and geochemical characteristics of the main ore-bearing rocks petrochemical types.

Tephrite. Structure is ophite, diabase. The rock is composed of divergent leisten of zonal plagioclase and isometric magnetite-biotite aggregates. Biotite is characterized by a short plate shape and green color, along cleavage the rutile and ilmenite allocation is marked. The rock is for the most part carbonated, enriched with phosphorus and fluorine than other petrochemical types listed in Table 1.

Trachybasalt (shoshonite). The texture of the unaltered rock is diabase, microophite, grain sizes are $0.1-0.7 \mathrm{~mm}$. Trachybasalt is composed by randomly directed leisten of twinned plagioclase (of andesine) and augite grains of irregular shape. The magnetite is closely associated with augite. Dykes of augite-andesine composition, during dynamometamorphism, in condition of the compression deformation, change the massive texture to the plane-oriented (trachytoid) and experience significant mineral transformations: andesine $\rightarrow$ oligoclase $\rightarrow$ sericite \pm quartz \pm carbonate $\rightarrow$ hydromica ("pelit"), augite $\rightarrow$ biotite or chlorite + ilmenite + rutile. Trachybasalts are characterized by higher contents of $\mathrm{TiO}_{2}$ and $\mathrm{P}_{2} \mathrm{O}_{5}$, lower-fluorine.

Trachyandesitebasalt (latite). Given in Table 1 analyses 5 - 7 of dyke rocks are referred to the petrochemical group of trachyandesitebasalts, petrographically represented by amphibole, and mica-plagioclase dynamo-slates. With this, the main latite minerals-hornblende and andesine are recorded as relict isolations, preserved in the secondary minerals mass of the deformational origin (for a hornblende-actinolite with ore minerals and chlorite, for an andesine-chlorite, sericite, hydromica, ore quartz in the form of veinlets). A characteristic petrographic feature of the considered rocks is the presence of potassium feldspar rims around sericite scales. Trachyandesitebasalts differ markedly from others discussed above petrochemical types of ore-bearing rocks by lower contents of $\mathrm{Cl}, \mathrm{P}_{2} \mathrm{O}_{5}$, and some higher ones $\mathrm{Cr}$ and $\mathrm{Ni}$. Their main feature is the presence of potassium varieties.

Petrochemical type "alkaline trachyte" is presented by cataclastic syenite with inclusions of aegerine-augite. The rock is composed of relatively large (3 - 5 $\mathrm{mm}$ ) deformed prisms of potassium feldspar filled with a dusty substance (pelite + colorless mica). Prisms deformation of the potassium feldspar is expressed in the granulation of their peripheral portions. The space between large grains is made by their small fragments, often with the correct habitus form and smooth faces of lattice microcline and newly formed short-prismatic plagioclase (albite-oligoclase). Clusters of small grains are observed in cracks that cross the rock. Large prisms deformation of feldspar is also expressed under a petrographic microscope in spindle-shaped extinction in crossed Nichols. Among the feldspar prismatic formations there are met small (up to $0.3 \mathrm{~mm}$ ) elongated grains of relict aegirine-augite, replaced by $70 \%-80 \%$ short plates of green biotite. 


\section{Ore Field Structure and Morphostructural Types of Ore Mineralization}

The whole complex of rocks that form Mykert-Sanzheevka ore field is intensively deployed, like other ore fields of Uda-Vitim metallogenic zone that belongs to the charriage-thrust tectonotype. The main ore localizing structures of ore field are losange ones (by [14]), similar to those that are widespread in the Ilya and Dibiksa gold deposits of the Onon-Turin branch, the Mongol-Okhotsk deep fault [15].

Losange structures of Mykert-Sanzheevka fields constitute mosaic clusters of rhombohedral and tetrahedral blocks-duplexes, separated by narrow tectonic sutures. These interblock sutures, made by subvolcanic dykes and dynamometamorphites (breccias, cataclasite, mylonites) and mechanometasomatites in the form of quartz, carbonate-quartz veins and argillisites, clusters of polycomponent ores are confined (Figure 2, Figure 3). Often dykes are boudinned and partly ore-bearing ones (Figure 3).

Grussy-crushed tectonoclastites we mentioned are considered as unlithified loosy tectonomixtites formed in the deformations zones during rocks mechanical destruction near the day surface [17]. They are usually referred to the group of kakirite facies dynamometamorphites. In the composition of tectonomixites in addition to the prevailing coarse fraction debris (boulders, gruss, gravel) B. M. Chikov [17] identifies milonit-slates matrix, which also includes clay component (friction clay) and powdery dispergiets. In our case, that is, within MykertSanzheevka field, ore, occurrence, essentially of noble-metal mineralization in kakerites are confined mainly to their matrix.

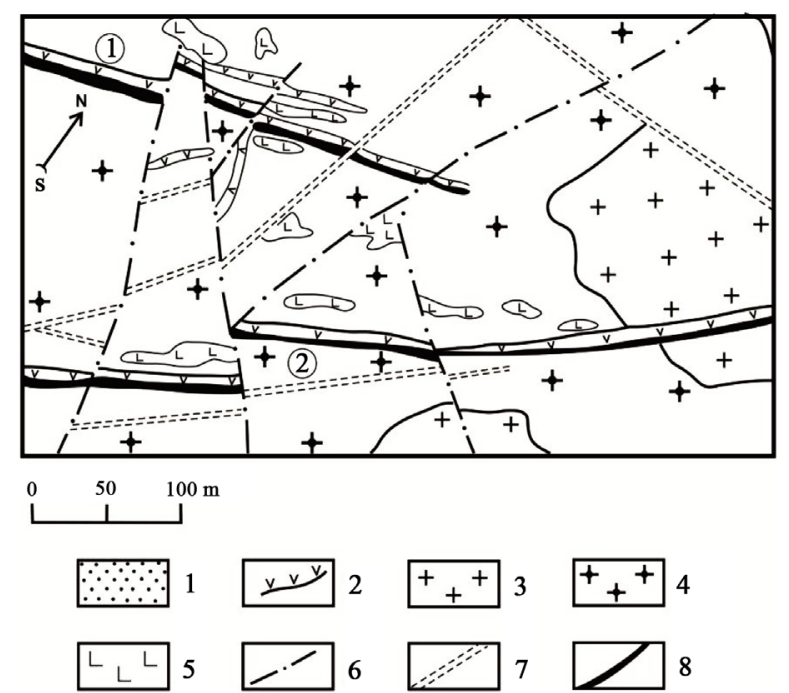

1 -Quaternary sediments; 2 - dykes of diorite porphyrites, microdiorites; 3 - fine-grained syenites; 4 - medium - coarse-grained syenites, quartz syenites; 5 - medium and fine - grained biotite diorites; 6 - faults allocated according to geophysical works data; 7 - zone of mylonitization, intense foliation; 8

- breccias zone with ore quartz-carbonate, carbonate-micaceous mechanometasomatites.

Figure 2. Geological map of the Small Mykert-Sanzheevka ore field deposits (according to V. F. Barsky, 1978 with the corrections of the article authors). 
$0 \quad 20 \quad 40 \mathrm{~m}$

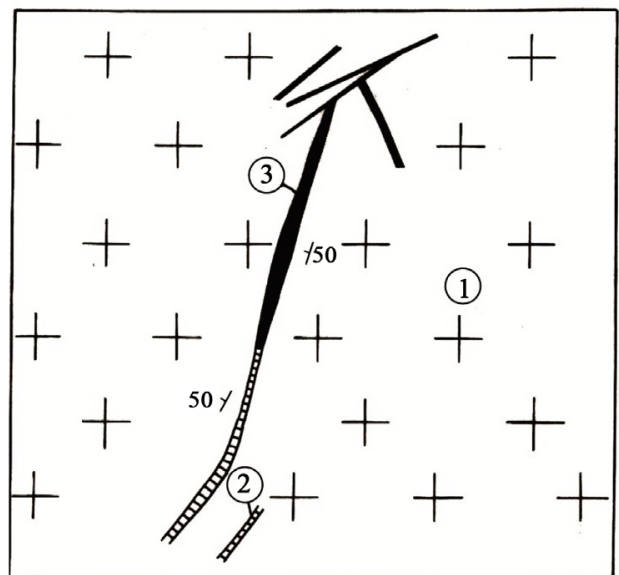

1 - syenites; 2 - boudinned latite dykes; 3 - hydromicaceous-chlorite formations on the rocks of dykes, with lenses, nests of massive and disseminated quartz-sphalerite-galena, sphalerite-galena ores with Ag, Au, Pt and Ru mineralization.

Figure 3. The ore body of lead-zinc with a noble metal ores (Sanzheevka area of Mykert-Sanzheevka ore field).

Dykes mostly create the initial (losange) frame of the ore field, fully inherited by the ore-bearing apodyke dynamometamorphites of cataclasite and mylonite facies. As show the detailed opening of ore bodies by surface mine workings and partly by drilling wells at the Small Mykert deposit, the ore-bearing ones are dynamometamorphites zones formed on the dyke bodies contacts with the syenites and presented by ore tectonobreccias with quartz-carbonate, carbonate-micaceous and galena veinlets (Figure 2).

A. L. Kowalewski with co-authors [7] [8] carried out researches on the delineation, using bio-geochemical and litho-geochemical anomalies, of MykertSanzheevka field disintegrated top surface below the soil layer in the depth interval from 1 to $2.5-5 \mathrm{~m}$. The result was the identification of platinum group elements (PGE) several morphological ("structural-formational") types localized in syenites and monocytes field: 1) complex silver-bearing (100 - $300 \mathrm{~m})$ and platinoid-bearing (up to $1000 \mathrm{~m}$ and more) stockworks; 2) steeply dipping (the fall angle is about $80^{\circ}$ ) platinoid-bearing local mineralized zones with a thickness of $0.2-2 \mathrm{~m} ; 3$ ) noble-metal mineralized zones of 2 - 20 m thickness; 4) platinoid-bearing stockwork zones with a width of $30-100 \mathrm{~m}$; 5) platinoid-bearing xenoliths of metamorphic and metasomatic rocks; 6) manto-like deposits of secondary hydrogenic or noble metal enrichment at a depth of $1-3 \mathrm{~m}$ near alkaline syenites and monzonites; 7) expected pocket-like deposits of secondary hydrogenic enrichment in zones of crushing and fracturing up to tens of meters deep.

All given above types of near-surface structural and morphological types of ore mineralization have no distinctive from endogenous structural and geological hypergenic signs of ore formation, inherent to ore-bearing weathering crusts or hydrogenic deposits.

Intensely crushed and fractured granitoids of shoshonite-latite series, in some 
areas (Figure 1) are turned into a crushed-gruss substrate.

About 110 - $120 \mathrm{~km}$ to North-East of Mykert-Sanzheevka ore field on the southern Ivolga depression side, Tsekhovsky J. G. with co-authors [16] studied in detail a tectonically disintegrated, sometimes silicified syenites and quartz syenites of the massif Tobhor called as tectonoclastites and are analogues to Mykert-Sanzheevka ones. The tectonoclastites grussy-crushed material of this massif is cemented by a sandy-clay matrix, often replaced by quartz, including forming veinlets.

\section{Deformational and Mineral Transformations of Ore Rock Complex}

Dynamometamorphic complex productive on polycomponent ores is regarded by the authors as a tectonic processing product of volcano-plutonic rocks shoshonite-latite series in the process of forming Mykert-Sanzheevka field structural frame. Primary aluminosilicate minerals composing unchanged rocks of this series, subjecting to cataclase and mineralization in the process of deformation effects under stress-metamorphism, experience solid-phase (mechanochemical) transformations, forming associations of newly formed minerals (Table 2).

The textures and structures of the initial rocks change in parallel. During diffusion mass transfer, accompanying friction sliding along the grain boundaries of the initial rocks, during crushing and abrading of the latter ones, the transition of the initial rock-forming components is performed in mineral forms that can accumulate scattered ore elements in dynamometamorphic minerals.

The most recent dynamometamorphites facies of Mykert-Sanzheevka field is represented by ore-bearing mechanometasomatites (in understanding of [17]) that finish deformational transformations of the primary initial rocks and dynamometamorphic rocks facies of the formation early stages.

Table 2. Mineral transformations peculiar properties of shoshonite-latite series rocks during cataclasite and mylonite facies dynamometamorphism.

\begin{tabular}{cl}
$\begin{array}{c}\text { Initial rocks subjected to } \\
\text { dynamometamorphism }\end{array}$ & $\begin{array}{l}\text { Initial rocks minerals and appeared on it secondary minerals of } \\
\text { deformational genesis }\end{array}$ \\
\hline Gabbro and monzonites & $\begin{array}{l}\text { Pyroxene } \rightarrow \text { hornblende, green biotite, light mica, ilmenite, sphen } \\
\text { Plagioclase (andesine) } \rightarrow \text { muscovite, K-feldspar } \\
\text { Hornblende } \rightarrow \text { actinolite, Fe-carbonate, biotite, chlorite, ilmenite }\end{array}$ \\
Syenites & $\begin{array}{l}\text { Andesine } \rightarrow \text { muscovite, albite-oligoclase, K-feldspar, quartz } \\
\text { Aegirine-augite } \rightarrow \text { green biotite } \\
\text { Biotite } \rightarrow \text { muscovite, rutile }\end{array}$ \\
Diorites & $\begin{array}{l}\text { Andesin-oligoclase } \rightarrow \text { sericite, albite, carbonate } \\
\text { Pyroxene } \rightarrow \text { chlorite, biotite }\end{array}$ \\
Dyke subvolcanic & $\begin{array}{l}\text { Andesine } \rightarrow \text { oligoclase, chlorite, sericite, K-feldspar, quartz, } \\
\text { carbonate, hydromica } \\
\text { Augite } \rightarrow \text { biotite, chlorite, ilmenite, rutile } \\
\text { complex }\end{array}$ \\
Hornblende $\rightarrow$ actinolite, chlorite
\end{tabular}


Two types of mechanometasomatites are allocated: 1) small veins, veinlets, lenses of micaceous-carbonate-quartz composition with ore mineralization; 2) zones, areas of argillizites made mostly of clay minerals. Mechanosomatites of the first type are usually composed of zonal construction quartz veinlets. Zoning is expressed by the presence of the bands quartz and quartz-carbonate-mica composition. Quartz is of two varieties. The first makes the main vein mass and is represented by large (up to $5-6 \mathrm{~mm}$ ) quartz grains of isometric and irregular shapes, dissected by parallel cracks on the plates oriented perpendicular to the banding. The second type of quartz grains is observed in the form of thin (up to 0.3 $\mathrm{mm}$ ) strips at the border of coarse-grained quartz and strips of quartz-carbonatemica composition. The bulk of this quartz (45\% - 30\%) is composed of chalcedonic gray quartz of pyramidal shape with smooth, but indistinct boundaries and unclear expressed extinction. The sizes of its grains are $0.05-0.15 \mathrm{~mm}$. In these zones, plates relics $(0.1-0.2 \mathrm{~mm})$ of the first variety early quartz are widespread, which as a result of dissolution acquired toothed outlines. In quartz aggregates there is widespread sericite admixture.

Fine-grained micaceous-carbonate-quartz aggregates form strips of 2 - $5 \mathrm{~mm}$, having clear boundaries. They do not contain any relics of early quartz. In this almost homogeneous mass, pyramidal formations (up to $0.1 \mathrm{~mm}$ ) of rutile, apatite and veinlet separations of the latest quartz appear. There are very thin new growths of zircon, rutile, tourmaline and ore minerals of acicular form, which are located along thin parallel fractures (possibly relict cleavage) feldspars, syenites, subjected to deep deformational transformations.

At the contact of shoshonite-latite series dykes in syenites the quartz-sericite formation sometimes substantially are formed with a small admixture of potassium carbonate nanophases (calicinite), Fe hydroxides (goethite) and Mg (brucite) in total not exceeding $5 \%$.

Ore-bearing argillisite type mechanometasomatites, composed mainly of sheet and chain silicates association (hydromuscovite, kaolinite, ferripyrophyllite, sepiolite, gibbsite), form the late separations in mechanometasomatites of micaceous-carbonate-quartz composition.

Ore accessory minerals of the aluminosilicate initial rocks listed in Table 2 and the secondary ore minerals of dynamometamorphites also experience solid-phase transformation (Table 3 ).

\section{Isotope-Geochemical Rb-Sr Age Determination of the Dynamometamorphic Ore-Rock Complex Formation}

Based on the data given in Table 4 an errorchron of $233 \pm 19$ million years age is obtained. It's close to the rocks formation time (233 - 188 million years) of West Transbaikalia sector volcano plutonic structure of the Mongol-Okhotsk rift zone, which includes Mykert-Sanzheevka ore field [10]. Taking into account that the considered dynamometamorphic ore-rock complex is the result of tectonometamorphic transformations of already appeared rocks composing the mentioned volcanoplutonic structure, the interval of 233 - 214 million years can 
Table 3. The deformation and mineral transformations scheme of ore minerals.

\begin{tabular}{cl}
\hline Initial ore minerals & New-formed minerals as a result of solid-phase (mechanochemical) reactions \\
\hline Ilmenite & Anatase, magnetite, sphene, pyrite \\
Magnetite & Martite, hematite, Fe-carbonate \\
Titanomagnetite & Magnetite, ilmenite, anatase, sphene \\
Galena & $\begin{array}{l}\text { Sphalerite, zincite, shapbahite }\left(\mathrm{AgBiS}_{2}\right) \text {, bournonite, argentite, } \\
\text { cerussite, anglesite, chalcopyrite, silvana (?), geocronite, sphalerite, } \\
\text { hematite, pale ore, cerussite, pyrite, galenobismutite, native } \mathrm{Pb}\end{array}$ \\
Sphalerite & $\begin{array}{l}\text { Hydromica Fe, chalcopyrite, zincite, sphalerite II, chalcocite, } \\
\text { hematite, alabandin, the smithsonite, bornite, bournonite }\end{array}$ \\
Chalcopyrite & Covellite, chalcocite \\
Bornite & Chalcocite, covellite, eskebornite, galena, pyrite, penzhinite, plattnerite
\end{tabular}

Table 4. Rb-Sr system isotopic characteristics of dynamometamorphic ore-rock complexes.

\begin{tabular}{clcccc}
\hline $\begin{array}{c}\text { Samples } \\
\text { numbers }\end{array}$ & \multicolumn{1}{c}{ Rocks characteristic } & $\mathrm{Rb}$ & $\mathrm{Sr}$ & ${ }^{87} \mathrm{Rb} /{ }^{86} \mathrm{Sr}$ & ${ }^{87} \mathrm{Sr} /{ }^{86} \mathrm{Sr}$ \\
\hline T-28A (6) & $\begin{array}{l}\text { Weakly cataclastic trachyandesitebasalt } \\
(\mathrm{Pb}=0.52 \text { wt\%, } \mathrm{Zn}=0.49 \text { wt\%) }\end{array}$ & 219.6 & 42.0 & 15.214 & 0.756315 \\
& $\begin{array}{l}\text { Sericite-chlorite dynamoslate on } \\
\text { trachyandesitebasalt with thin veinlets } \\
\text { of galena-quartz composition } \\
\text { (Pb } 1.5 \text { wt\%, Zn = 0.43 wt\%) }\end{array}$ & 224.7 & 51.3 & 12.728 & 0.749498 \\
& $\begin{array}{l}\text { Tectonobreccia on diorites with } \\
\text { weak sulphide mineralization }\end{array}$ & 12.3 & 60.0 & 0.592 & 0.709840 \\
T-21A & Hematite ore with galena (wt\%) & 4.6 & 35.3 & 0.379 & 0.707716 \\
CЖ-9 & $\begin{array}{l}\text { Chlorite-amphibole dynamoslate } \\
\text { T-23 (4) }\end{array}$ & 45.8 & 1252 & 0.106 & 0.705866 \\
\hline
\end{tabular}

Note: in parentheses-number of analyses given in Table 1. Definitions were made on the mass-spectrometer MU 1201T V.F. Posokhov.

be considered the most probable dating of such transformations. It is assumed that the dynamometamorphism and ore genesis processes, occurred in several temporal stages are within the range of 19 million years.

\section{Mineralogical-Geochemical Peculiar Properties of Dynamometamorphic Origin Ore Mineralization}

Ore mineralization is represented by continuous and nest-disseminated sulfide separations, usually with a galena prevailing. The species composition of ore minerals is given in Table 4. Note that besides visual individuals of galena, sphalerite, magnetite, sometimes chalcopyrite, argentite, pyrite, native gold, other ore minerals have micro- and nanosizes.

There are distinguished 4 time formation stages of dynamometamorphites characterized by different species compositions of forming ore minerals (Table $5)$. 
Table 5. Ore minerals in dynamometamorphic genesis ore-bearing rocks of different stages formation.

\begin{tabular}{|c|c|}
\hline Stages of dynamometamorphism & Typical ore minerals \\
\hline $\begin{array}{l}\text { I Stage. Mainly cataclastic facies. Deformational } \\
\text { transformations of initial rocks minerals }\end{array}$ & $\begin{array}{l}\text { Ilmenite }\left(\mathrm{FeTiO}_{3}\right) \text {, geikrimite }\left(\mathrm{MgTiO}_{3}\right) \\
\text { rutile }\left(\mathrm{TiO}_{2}\right) \text {, magnetite }\left(\mathrm{Fe}_{3} \mathrm{O}_{4}\right) \text {, pyrite }\left(\mathrm{FeS}_{2}\right) \text {, }\end{array}$ \\
\hline $\begin{array}{l}\text { II Stage. Cataclastic and mylonit facies. } \\
\text { Deformational transformation of initial } \\
\text { rocks minerals and I stage cataclasites }\end{array}$ & $\begin{array}{l}\text { Hematite }\left(\mathrm{Fe}_{2} \mathrm{O}_{3}\right) \text {, iocite }(\mathrm{FeO}) \text {, tenorit }(\mathrm{CuO}) \text {, zincite }(\mathrm{ZnO}) \text {, } \\
\text { plattnerite }\left(\mathrm{PbO}_{2}\right) \text {, magnetoplumbite }\left(\mathrm{PbFe}_{12} 4 \mathrm{O}_{19}\right) \text {, } \\
\text { anatase }\left(\mathrm{TiO}_{2}\right) \text {, galena }(\mathrm{PbS}) \text {, sphalerite }(\mathrm{ZnS}) \text {, } \\
\text { boulangerite }\left(\mathrm{Pb}_{2} \mathrm{Sb}_{4} \mathrm{~S}_{11}\right) \text {, bournonite }\left(\mathrm{CuPbSbS}_{3}\right) \text {, } \\
\text { covellite }(\mathrm{CuS}) \text {, chalcocite }\left(\mathrm{Cu}_{2} \mathrm{~S}\right) \text {, emplectite }\left(\mathrm{CuBiS}_{2}\right) \text {, } \\
\text { bornite }\left(\mathrm{Cu}_{5} \mathrm{FeS}_{4}\right) \text {, tetrahedrite }\left(\mathrm{Cu}_{12} \mathrm{Sb}_{4} \mathrm{~S}_{13}\right) \text {, antimonite }\left(\mathrm{Sb}_{2} \mathrm{~S}_{3}\right) \text {, } \\
\text { bismuthine }\left(\mathrm{Bi}_{2} \mathrm{~S}_{3}\right) \text {, argentite }\left(\mathrm{Ag}_{2} \mathrm{~S}\right) \text {, stroymerite }(\mathrm{AgCuS}) \\
\text { penzhinite }(\mathrm{AgS}) \text {, pyrargyrite }\left(\mathrm{Ag}_{3} \mathrm{SbS}_{3}\right) \text {, matildite }\left(\mathrm{AgBiS}_{2}\right) \text {, } \\
\text { native } \mathrm{Pb}, \mathrm{Ag}, \mathrm{Au}\end{array}$ \\
\hline $\begin{array}{l}\text { III Stage. Mylonite facies with the } \\
\text { mechanometasomatites formation of quartz, } \\
\text { carbonate-quartz, and sulfide composition }\end{array}$ & $\begin{array}{l}\text { Plattnerite, massicot }(\mathrm{PbO}) \text {, galena }(\mathrm{PbS}) \text {, sphalerite }(\mathrm{ZnS}) \text {, } \\
\text { pyrite }\left(\mathrm{FeS}_{2}\right) \text {, chalcopyrite }\left(\mathrm{CuFeS}_{2}\right) \text {, bornite, eskebornite }\left(\mathrm{CuFeSe}_{2}\right) \text {, } \\
\text { covellite }(\mathrm{CuS}) \text {, chalcocite, penzhinite, cencosite }\left(\mathrm{ZnSO}_{4}\right) \text {, } \\
\text { smithsonite }\left(\mathrm{ZnCO} \mathrm{Zn}_{3}\right) \text {, cerussite }\left(\mathrm{PbCO}_{3}\right) \text {, } \\
\text { native } \mathrm{Pb}, \mathrm{Ag}, \mathrm{Au} \text {, intermetallics, } \mathrm{Ag}-\mathrm{Mo}, \mathrm{Ag}-\mathrm{Pb}-\mathrm{Mo}\end{array}$ \\
\hline $\begin{array}{l}\text { IV stage. Mechanometasomatites mainly with } \\
\text { aqueous minerals }\end{array}$ & $\begin{array}{l}\text { Volborthite }\left(\mathrm{Cu}\left[\mathrm{VO}_{4}\right]_{2} \cdot 3 \mathrm{H}_{2} \mathrm{O}\right) \text {, tangeite }\left(\mathrm{CaCuVO}_{4} \mathrm{OH}\right) \text {, } \\
\text { motramite }(\mathrm{PbCuVO} 4 \mathrm{OH}) \text {, chlorargyrite }(\text { cerargyrite })(\mathrm{AgCl}) \text {, } \\
\mathrm{Ag}_{2} \mathrm{SO}_{4} \cdot 5 \mathrm{H}_{2} \mathrm{O}, \mathrm{Ag}(\mathrm{OH})_{2} \text {, szomolnokite }\left(\mathrm{FeSO}_{4} \cdot \mathrm{H}_{2} \mathrm{O}\right) \text {, } \\
\text { goethite }\left(\mathrm{HFeO}_{2}\right) \text {, anglesite }\left(\mathrm{PbSO}_{4}\right) \text {, } \\
\text { zincoside, nanophases of native } \\
\text { noble metals }\end{array}$ \\
\hline
\end{tabular}

Among these minerals, the main role in the composition of ore clusters belongs to galena, sphalerite and pyrite. As shown in Table 3, galena is the primary matrix for the various groups of minerals represented mostly by sulfides and oxides. Ore sulphates, carbonates, native metals were also diagnosed.

Galena is mostly represented by fine-grained aggregates with small (0.08 $0.12 \mathrm{~mm}$ ) isometric, slightly flattened, grains with uneven curved boundaries. Fine-grained structure is found in the galena by etching with concentrated hydrochloric acid. When etching galena for 7 minutes, its dark gray short and white plates appear in accretion with white-gray smaller ones, forming a intersecting lattice microstructure and presented by sulfides of different composition $(\mathrm{Cu}, \mathrm{Bi}, \mathrm{Sb}, \mathrm{Zn}, \mathrm{Ag}, \mathrm{Fe})$. These sulfides are grouped into separate microinclusions $(10-20 \mu \mathrm{m})$ not only in the form of short plates, but also isometric grains tending to cleavage cracks. Small $(0.01-0.05 \mathrm{~mm})$ inclusions of chalcopyrite and pyrite are relatively widespread in galena. Pyrite forms skeleton porphyroblasts containing microinclusions of galena and chalcopyrite. In zones of intense foliation the pyrolusite, covellite, chalcocite, cerussite, anglesite appear. Covellite and chalcocite occur in small amounts, together forming thin scales in cerussite.

The authors studied in detail the ore minerals microaggregates with size from $5.0 \times 2.5 \mu \mathrm{m}$ to $2.5 \times 1.3 \mu \mathrm{m}$ in some galena ore samples that concentrate "invisible" $\mathrm{Au}$ in a wide range of contents from 0.07 to $0.69 \mathrm{wt} \%$ (Table 6). Table 6 data analysis showed that there is no direct correlation between the values of $\mathrm{Au}$ and most other ore elements. Only positive correlation for $\mathrm{Au}-\mathrm{Cu}$ concentra- 
tions is found.

At the same time, between the contents in $\mathrm{Au}-\mathrm{Pb}$ and $\mathrm{Au}-\mathrm{Ag}$ pairs, a possible relationship is seen, which is approximated by the sinusoid $y=\sin x$ ( $y=A u$, and $x=\mathrm{Pb}$ and $\mathrm{Ag}$ ). An adequate reflection of the marked stochastic geochemical relations is the variability nature of the mineral associations species composition making microinclusions in galena ores (Table 6) as the content of "invisible" gold increases. It should be noted that the maximum content of $\mathrm{Au}(0.69 \mathrm{wt} \%)$, is identified in micro-inclusion containing nanoparticles of native $\mathrm{Ag}$ and oxides.

Sphalerite, which is the second by the prevalence (5-20 vol\%) ore mineral of Mykert-Sanzheevka field, forms two generations. I-dark gray, with a smooth surface, without the characteristic sphalerite twins and decay structures. It forms polygonal aggregates extended along quartz veinlets, often bordering larger galena aggregates. In the contact zones of these two ore minerals, their mutual penetration into each other is sometimes observed. More often, these zones are made by late minerals that replace both galena and sphalerite from the periphery and along cleavage cracks. The sphalerite I reflectance is low, the color is gray

Table 6. Characteristics of associations species composition of ore minerals micro-and nanophases containing “invisible” gold.

\begin{tabular}{|c|c|c|c|}
\hline \multirow{2}{*}{$\begin{array}{l}\text { Contents of } \\
\text { "invisible" } \\
\text { Au wt\% }\end{array}$} & \multicolumn{3}{|c|}{ Ore mineral associations } \\
\hline & Main minerals & Secondary minerals & Accessory minerals \\
\hline 0.07 & $\begin{array}{l}\text { Galena }(\mathrm{PbS}) \\
\text { tetrahedrite }\left(\mathrm{Cu}_{12} \mathrm{Sb}_{4} \mathrm{~S}_{19}\right)\end{array}$ & $\begin{array}{l}\text { Penzhinite }(\mathrm{AgS}) \\
\text { antimonite }\left(\mathrm{Sb}_{2} \mathrm{~S}_{3}\right)\end{array}$ & $\begin{array}{l}\text { Sphalerite }(\mathrm{ZnS}) \\
\text { bismuthine }\left(\mathrm{Bi}_{2} \mathrm{~S}_{3}\right) \text {, } \\
\text { hematite }\left(\mathrm{Fe}_{2} \mathrm{O}_{3}\right)\end{array}$ \\
\hline 0.10 & $\begin{array}{l}\text { Goethite }\left(\mathrm{HFeO}_{2}\right) \text {, } \\
\text { native } \mathrm{Ag} \text {, melanterite }\left(\mathrm{FeSO}_{4} \cdot 7 \mathrm{H}_{2} \mathrm{O}\right)\end{array}$ & Anglesite $\left(\mathrm{PbSO}_{4}\right)$ & $\begin{array}{l}\text { Chalcantite }\left(\mathrm{CuSO}_{4} \cdot 5 \mathrm{H}_{2} \mathrm{O}\right) \\
\text { goslarite }\left(\mathrm{ZnSO}_{4} \cdot 7 \mathrm{H}_{2} \mathrm{O}\right)\end{array}$ \\
\hline 0.12 & $\begin{array}{l}\text { Galena, } \\
\text { argentite }\left(\mathrm{Ag}_{2} \mathrm{~S}\right)\end{array}$ & Hematite $\left(\mathrm{Fe}_{2} \mathrm{O}_{3}\right)$ & $\begin{array}{l}\text { Chalcopyrite }\left(\mathrm{CuFeS}_{2}\right) \text {, } \\
\text { szomolnokite }\left(\mathrm{FeSO}_{4} \cdot \mathrm{H}_{2} \mathrm{O}\right) \\
\text { sphalerite }\end{array}$ \\
\hline 0.25 & Tetrahedrite, galena & Argentite, antimonite & $\begin{array}{l}\text { Sphalerite, pyrite, } \\
\text { bismuthine }\end{array}$ \\
\hline 0.36 & Tetrahedrite, galena & Argentite, antimonite & $\begin{array}{l}\text { Sphalerite, bismuthine, } \\
\text { hematite }\end{array}$ \\
\hline 0.48 & $\begin{array}{l}\text { Argentite, } \\
\text { stroymerite (AgCuS) }\end{array}$ & Galena & Pyrite $\left(\mathrm{FeS}_{2}\right)$, hematite \\
\hline 0.50 & Tetrahedrite, galena, penzhinite & Antimonite & Szomolnokite, bismuthine \\
\hline 0.55 & Tetrahedrite, penzhinite & Antimonite, galena & Szomolnokite, zincosid $\left(\mathrm{ZnSO}_{4}\right)$, bismuthine \\
\hline 0.69 & Galena & $\begin{array}{l}\text { Iocite }(\mathrm{FeO}) \text { native } \mathrm{Ag} \text {, } \\
\text { plattnerite }\left(\mathrm{PbO}_{2}\right)\end{array}$ & Zincite, tenorit \\
\hline
\end{tabular}

Note: The content of Au and the elemental composition of minerals are determined by I.G. Bystrov (VIMS) on the JXA-8100 microanalyzer of Jed Ltd, ecuipped with three wave spectrometrs and energy dispersal console Link Pentafet. 
with a brownish tint. Isotropic, by portions, a weak anisotropy is observed, the solid solutions decay structures were not observed, galena inclusions (0.01 - 0.1 $\mathrm{mm})$ are marked. Sphalerite is later and replaces sphalerite-I in the form of borders from the grain boundaries to the center and by cleavage. Sometimes it replaces the grain completely. It is characterized by higher reflectance and bluish tint, isotropic, internal reflexes are typical. Iron hydroxides develop on sphalerite-II. No decay structures were found in it.

Sphalerite, as galena, was subjected to dynamometamorphism with oxidation. The total content of the resulting minerals varies within $5-47 \mathrm{vol} \%$. The most common of them are cerussite, limonite, chalcocite. In smaller quantities, but everywhere anglesite and smithsonite are observed.

Pyrite is the third, in occurrence, ore mineral in ores with noble metals. The physical properties of pyrite are close to standard ones. It forms mainly small $(0.02-0.1 \mathrm{~mm})$ inclusions in galena and is in close accretion with it, associating with chalcopyrite. The shape of pyrite grains is cubic, the largest $(0.15-0.4 \mathrm{~mm})$ of them are porphyroblasts and have a cribriform microstructure due to the inclusions of galena, sphalerite and quartz. Pyrite as well as galena and sphalerite in zones of intense dynamometamorphism are replaced by limonite.

Chalcopyrite associating with pyrite was found as microinclusions $(0.01$ $0.05 \mathrm{~mm}$ ) in galena. In some galena specimens chalcopyrite inclusions partially $(50 \%)$ are replaced by chalcocite.

Silver mineral form represent a particular interest for the study because the high content of this element in ore-rock complex was allowed to consider it as a major industrial component in prospecting and exploration of Mykert-Sanzheevka field ore zones and deposits. The identified Ag minerals do not form, as $\mathrm{Pb}, \mathrm{Zn}$, $\mathrm{Cu}$ or $\mathrm{Fe}$, as well as part of the native Au visible by the naked eye individual minerals or their clusters. They are found in the form of micro- and nanophases not only in visually distinct galena ores (argentite, stroymerite, penzhinite, cerargyrite, native $\mathrm{Ag}$ ), but also in clayey formations of argillizite mechanometsomstites not having other ore elements mineralization (Figure 4). Only here they are represented by sulphates $\left(\mathrm{Ag}_{2} \mathrm{SO}_{4} \cdot 2 \mathrm{H}_{2} \mathrm{O}, \mathrm{Ag}_{2} \mathrm{SO}_{4} \cdot 5 \mathrm{H}_{2} \mathrm{O}\right)$ and hydroxide $\mathrm{Ag}(\mathrm{OH})_{2}$ emissions with sizes from $200 \times 200 \mathrm{~nm}$ to worm-like separations with thickness of $200-650 \mathrm{~nm}$, length from 1.2 to 13 microns or more.

\section{On the Occurrence Forms of Platinum Group Elements in Dynamometamorphic Complex Rocks and Ores}

Substance composition detailed researches of the ore-bearing complexes in noble metal deposits significant number in order to develop the ore enrichment and technologies effective methods for the most complete extraction of $\mathrm{Au}, \mathrm{Ag}$ and PGE allowed to establish a wide development of these elements cluster forms, concentrating the bulk of these elements [18]. It is assumed that the primary metal-organic clusters with the outer carbon shells, named by V. N. Matvienko with co-authors the proto-clusters are the metal-extracting paleo-bacteria. 


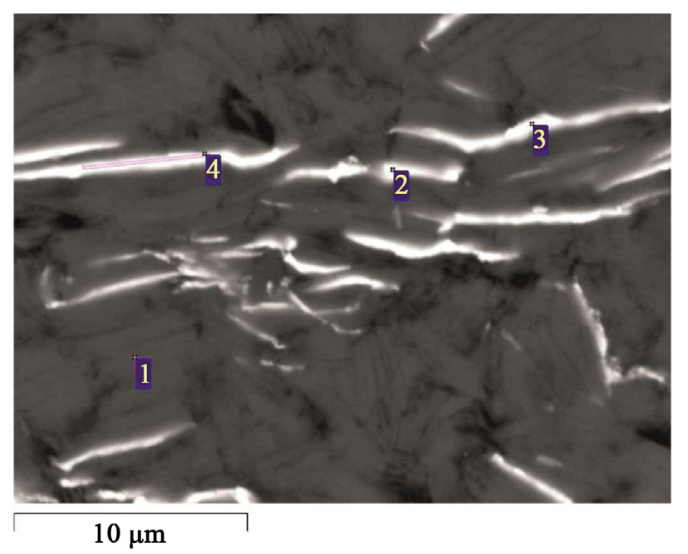

Paragenetic mineral associations at the points of microprobe analysis calculated from the stoichiometric ratios of chemical elements: 1 - muscovite (85.1), quartz (8.1), calcinite (2.6), goethite (1.3), brucite (0.7); $2-\mathrm{Ag}_{2} \mathrm{SO}_{4} \cdot 2 \mathrm{H}_{2} \mathrm{O}$ sulfate (33.8), Ag hydroxide $(\mathrm{OH})_{2}$ (30.2), illite (23.3), kaolinite (8.5) ferripyrophilite (1.7), sepiolite (1.4), gibbsite (0.6); 3 - $\mathrm{Ag}(\mathrm{OH})_{2}$ (35.3) hydroxide, $\mathrm{Ag}_{2} \mathrm{SO}_{4} \cdot 5 \mathrm{H}_{2} \mathrm{O}$ sulfate (32.2), illite (22.0), kaolinite (4.3), ferripyrophilite (2.3), sepiolite (1.2); $4-\mathrm{Ag}_{2} \mathrm{SO}_{4} \cdot 5 \mathrm{H}_{2} \mathrm{O}$ (55.0) sulfate, illite (20.5), $\mathrm{Ag}(\mathrm{OH})_{2}$ (11.5) hydroxide, kaolinite (5.4), gibbsite (3.2), ferripyrophillite (3.0), sepiolite (1.2). Diagnosed according to the result of the elemental analisis perfomed I.G.Bystrov (VIMS) on mikroanalizatore GXA-8100 firm Jed Ltd. In parentheses, the contents are in percentages.

Figure 4. Nano-silver trace minerals in argillizite mechanometasomatites of MykertSanzheevka ore field.

These proto-clusters after transforming themselves in noble metals native phase, i.e. after their metallization, resulted into ore material accumulations, including platinoids in occurrences of the auriferous deposits various types (Bakyrchik, Baley, Kumtor, Nezhdaninsk, etc.) [18]. At the same time, an important, if not decisive role is established in the destruction of primary organometallic clusters-the dynamometamorphism processes accompanied by oxidation. The paragenesis of noble metals metastable phases evolving in time, but combined in space.is shown against the background of tectonic-metamorphic transformations increasing intensity. It looks like: metastable protocluster organometallic (chlorides, sulfates) $\rightarrow$ (sulfuric sulfides, tellurides, selenites) $\rightarrow$ colloidal forms $(\mathrm{MenOHb}) \rightarrow$ aggregative native forms. The given idealized evolutionary scheme can be violated because of multiple deformational transformations acts of ore-rock complexes and the mechanochemical reactions intensity.

A large role in ore formation, including noble metal and complex mineralization, is given to organoelement compounds represented by metal carbonils and related to the compounds (carbonyl hydrides, carbonyl halides, carbonils organic derivatives etc.) [19] [20]. It is assumed that the primary associations evolution of platinum group mantle minerals in ultrabasites took place in the form of carbonyl compounds under the action of strongly recovered fluids [21]. According to [22] data, the formation of ore-forming carbonyl complexes, their involvement in the field of ore genesis, greatly stimulate the processes of dynamometamorphism. Herewith, thermal dissociation, hydrolysis, oxidation of carbonils, leading to the formation of oxides, hydroxides and native metals are the result of their molecules strong deformations. 
We propose carbonyl model of noble metals nano- and microparticles formation in polycomponent ores of Mykert-Sanzheevka field that is substantiated by a number of signs, characteristic to chemical technologies for producing metal films and coatings [23] [24] [25].

1) Wide distribution of metal polyelement oxide microfilms (Table 7, Figure 5) containing nanophases of noble metals. Microfilms have substrates with graphite, graphite oxides. The existing methods and mechanisms of low-temperature carbonyl metal films and coatings formation cannot be implemented without substrates with a heated surface. In our case, the considered conditions of carbonyl compounds metallization and/or their clusters (friction heating, oxidation) are created by a deformation (tribochemical) mechanism.
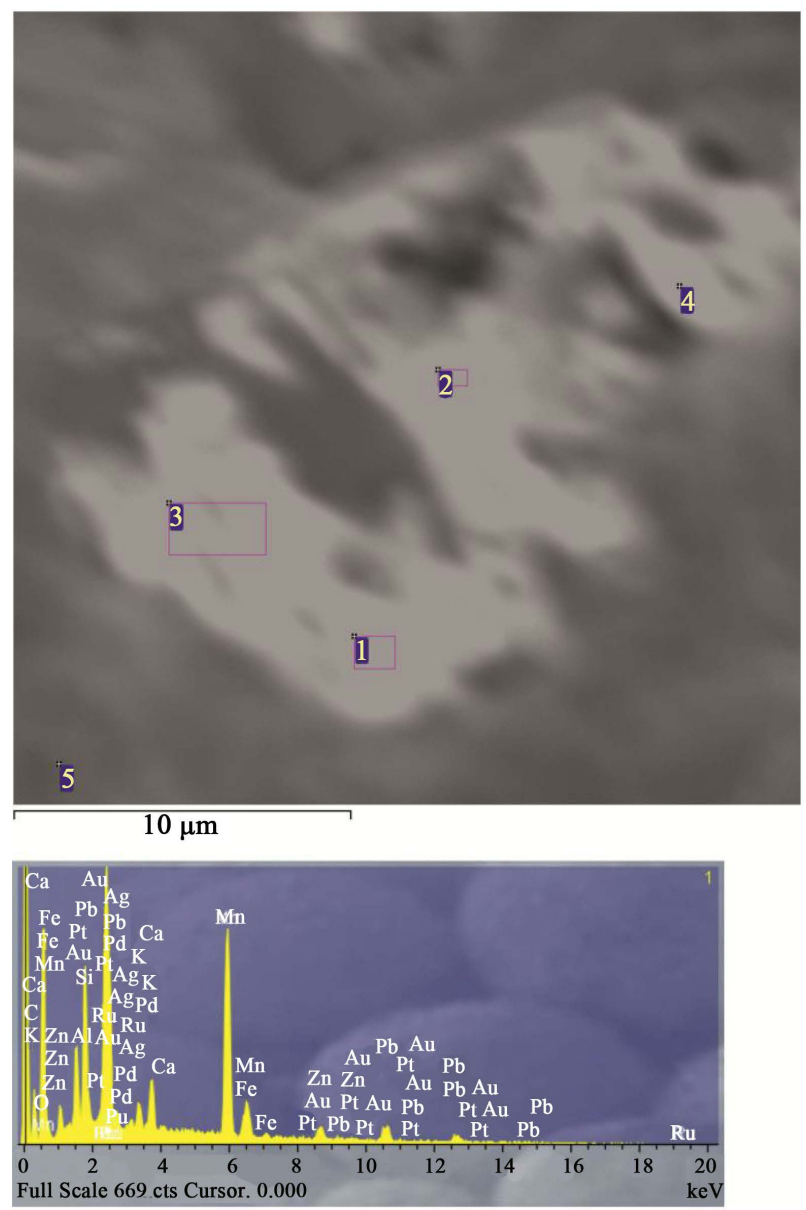

1 - plattnerite (34.2), manganite (33.3), muscovite (14.8), portlandite (4.8), quartz (4.5), zincite (4.5), goethite (3.4); 2 - plattnerite (31.9), manganite (30.7), muscovite (12.5), portlandite (9.2), quartz (5.9), zincite (4.2), goethite (3.7), kaolinite (1.8); 3 - plattnerite (36.6), manganosite (32.1), muscovite (13.7), zincite (5.0), wollastonite (4.5), goethite (3.2), quartz (2.7), kaolinite (1.7), the portlandite (0.7); 4 - plattnerite (30.1), manganite (22.4), Muscovite (13.1), manganosite (7.6), quartz (6.4), portlandite (5.9), goethite (5.8), zincite (5.2), kaolinite (3.4); 5 - the substrate composition of the ore microfilm: muscovite (55.8), quartz (10.0), hematite (6.6), Mg-chlorite (3.6), nahcolite (2.5), graphite oxide $\mathrm{C}_{2} \mathrm{O}_{3}$ (7.5), graphite (9.3). The numbers in parentheses are contents in percentages.

Figure 5. Ore microfilm $(20 \times 12 \mu \mathrm{m})$ with nanophases of noble metals (piece of polished section T-29A). 
Table 7. The elemental composition of the ore microfilm with noble metals, appeared on a mechanometasomatites substrate.

\begin{tabular}{ccccccccccccc}
\hline Analysis points in Figure 5 & $\mathrm{C}$ & $\mathrm{O}$ & $\mathrm{Na}$ & $\mathrm{K}$ & $\mathrm{Si}$ & $\mathrm{Al}$ & $\mathrm{Ca}$ & $\mathrm{Mg}$ & $\mathrm{Mn}$ & $\mathrm{Fe}$ & $\mathrm{Zn}$ & $\mathrm{Pb}$ \\
\hline 1 & - & 29.46 & - & 1.55 & 5.20 & 2.98 & 2.57 & - & 22.88 & 2.13 & 3.58 & 29.60 \\
2 & - & 30.67 & - & 1.22 & 5.77 & 2.92 & 5.02 & - & 21.12 & 2.31 & 3.87 & 27.60 \\
3 & - & 25.49 & - & 1.34 & 5.58 & 3.13 & 1.94 & - & 24.82 & 2.00 & 4.01 & 31.69 \\
4 & - & 31.96 & - & 1.29 & 6.53 & 3.39 & 3.17 & - & 19.71 & 3.66 & 4.21 & 26.08 \\
5 & 14.32 & 41.63 & 0.68 & 5.73 & 17.12 & 11.36 & - & 0.93 & 3.64 & 4.59 & - & - \\
\hline
\end{tabular}

Note: 1 - 4-ore microfilm with nanophases of noble metals fixed in energy spectra; 5-carbonaceous mechanometasomatites substrate. The tests were performed on the scanning electron microscope LEO 1430 VP E.A. Khromova (GIN SO RAS).

2) Mineralogic and geochemical signs of oxidative mineral microaggregates decarbonylation and formation with discrete noble metals nanoparticles fixed on energy spectra shown in Table 8 and Table 9. There were identified 7 types of mineral microaggregates. Herewith, in six of them, Pb-plattnerite oxide is present in the composition of ore oxide associations. Thus, this mineral can be considered as platinoid mineralization indicator of Mykert-Sanzheevka ore field.

All seven identified mineral types are enriched to the greatest extent with nanoparticles of native Pt, and six of them with Pd. Spectral energy peaks are also found for ruthenium microphases. These facts are consistent with the previously established platinum-ruthenium ore-geochemical specialization of the MykertSanzheevka field polymetallic ores [1].

3) The structure and composition of PGE geochemical microfields in those ore microaggregates, where there are no their peaks in the energy spectra (Table 10). The characteristic morphostructural surface relief, peculiar to metal coatings is not only adequately reflected in the components geochemical microfields usually intrinsic to carbonyl compounds (volatile hydrocarbons, $\mathrm{S}, \mathrm{Cl}, \mathrm{F}, \mathrm{H}_{2} \mathrm{O}$ pairs), but is also emphasized by the uniformly discrete distribution of Pt mineral nanoparticles.

\section{The Results Discussion: Geologic-Genetic Peculiar Properties of Mykert-Sanzheevka Field Ore-Forming System Formation}

Structural-geological and mineralogic-geochemical data obtained by the authors, in total with predecessors published materials allow to consider the proposed evolutionary model main traits of the Mykert-Sanzheevka field ore-forming system (OFS) formation (Table 11). Below we give a description of such OFS important elements as of fluids sources and ore substance, the concentration mechanisms of the latter one.

Fluids sources. Proposed above organometallic carbonyl model of ore genesis assumes as the ore elements migration and accumulation main agents-volatile compounds represented by hydrocarbons (methane, ethane, etc.) $\mathrm{CO}, \mathrm{CO}_{2}$, and by $\mathrm{S}, \mathrm{Cl}, \mathrm{F}, \mathrm{H}_{2} \mathrm{O}$ vapors. From our point of view, they are formed in the processes of dynamometamorphism due to the deformational (mechanochemical) mechanism 
Table 8. The composition of mineral microaggregates of mechanometasomatites characterized by the presence of energy spectra with noble metals.

\begin{tabular}{|c|c|c|c|c|c|c|c|c|c|c|c|c|c|}
\hline $\begin{array}{l}\text { Numbers of } \\
\text { polished } \\
\text { sections }\end{array}$ & $\begin{array}{l}\text { Sites } \\
\text { (analysis points } \\
\text { in parentheses) }\end{array}$ & $S$ & $\mathrm{O}$ & $\mathrm{Pb}$ & $\mathrm{Zn}$ & $\mathrm{Fe}$ & $\mathrm{Mg}$ & $\mathrm{Mn}$ & $\mathrm{Ti}$ & $\mathrm{Si}$ & $\mathrm{K}$ & $\mathrm{Ca}$ & $\mathrm{Al}$ \\
\hline 1 & S.1-1 (1) & 12.50 & 2.29 & 82.89 & - & 1.16 & - & - & - & 1.16 & - & - & - \\
\hline 2 & S.2(4) & 9.41 & 12.92 & 66.32 & 1.11 & 2.10 & - & - & - & 5.98 & 0.72 & 0.31 & 0.93 \\
\hline 3 & S.3 (3) & 5.93 & 32.02 & 38.02 & - & 3.16 & - & - & - & 18.32 & 0.93 & - & 1.62 \\
\hline 4 & S.1-1-1 (1) & - & 29.47 & 29.64 & 3.58 & 2.13 & - & 22.88 & - & 5.20 & 1.55 & 2.57 & 2.98 \\
\hline 5 & $\mathrm{~S} .4(2)$ & - & 24.33 & 63.50 & - & 3.52 & 0.58 & - & - & 4.57 & 0.94 & - & 2.56 \\
\hline 6 & S.3 (2) & - & 35.79 & 14.73 & 1.33 & 32.85 & - & - & - & 10.81 & 1.09 & 0.51 & 2.89 \\
\hline 7 & S.3 (6) & - & 39.15 & 4.38 & 2.84 & 34.90 & 0.65 & - & 0.39 & 11.48 & 1.42 & - & 4.79 \\
\hline
\end{tabular}

Note: polished sections: 1 -sample K-12, 2 - 7-sample T-29A. Samples are represented by mechanometasomatites on the apodyke ore-bearing dynamometamorphites. The gross chemical composition of the T-29A sample is given in Table 1 (analysis 7). Associations composition (in parentheses-percentages of micro- and nanophases contents): 1 -galena (93.3), quartz (2.5), plattnerite (2.4), hematite (1.7); 2-galena (50.2), anglesite (25.5), quartz (7.6), native Pb (5.6), K-feldspar (5.2), anortite (2.2), native Fe (2.1) and $\mathrm{Zn} \mathrm{(1.1);} \mathrm{3-quartz} \mathrm{(34.8),} \mathrm{plattnerite} \mathrm{(26.7),} \mathrm{anglesite} \mathrm{(21.8),} \mathrm{muscovite} \mathrm{(9.5),} \mathrm{pyrite} \mathrm{(6.8),} \mathrm{kaolinite}$ (0.3); 4-plattnerite (34.2), manganite (33.3), muscovite (14.8), portlandite (4.8), zincite (4.5), goethite (3.4); 5-plattnerite (73.4), muscovite (9.6), ferrihydrite $\mathrm{Fe}(\mathrm{OH})_{2} \cdot 3 \mathrm{H}_{2} \mathrm{O}$ (8.6), quartz (3.2), kaolinite (2.9), Mg-chlorite (2.2); 6-goethite (31.9), hematite (18.8), plattnerite (17.0), quartz (16.2), muscovite (11.1), anortite (3.4), zincite (1.7); 7-goethite (26.0), hematite (25.8), muscovite (14.5), quartz (13.0), kaolinite (8.5), massicot (4.7), zincite (3.5), Mg-chlorite (2.5), ilmenite (1.2). The tests were performed on the scanning electron microscope LEO 1430 VP E.A.Khromova (GIN SO RAS).

Table 9. The most feasible compositions of noble metal nanophases in various mineral types of ore microaggregates.

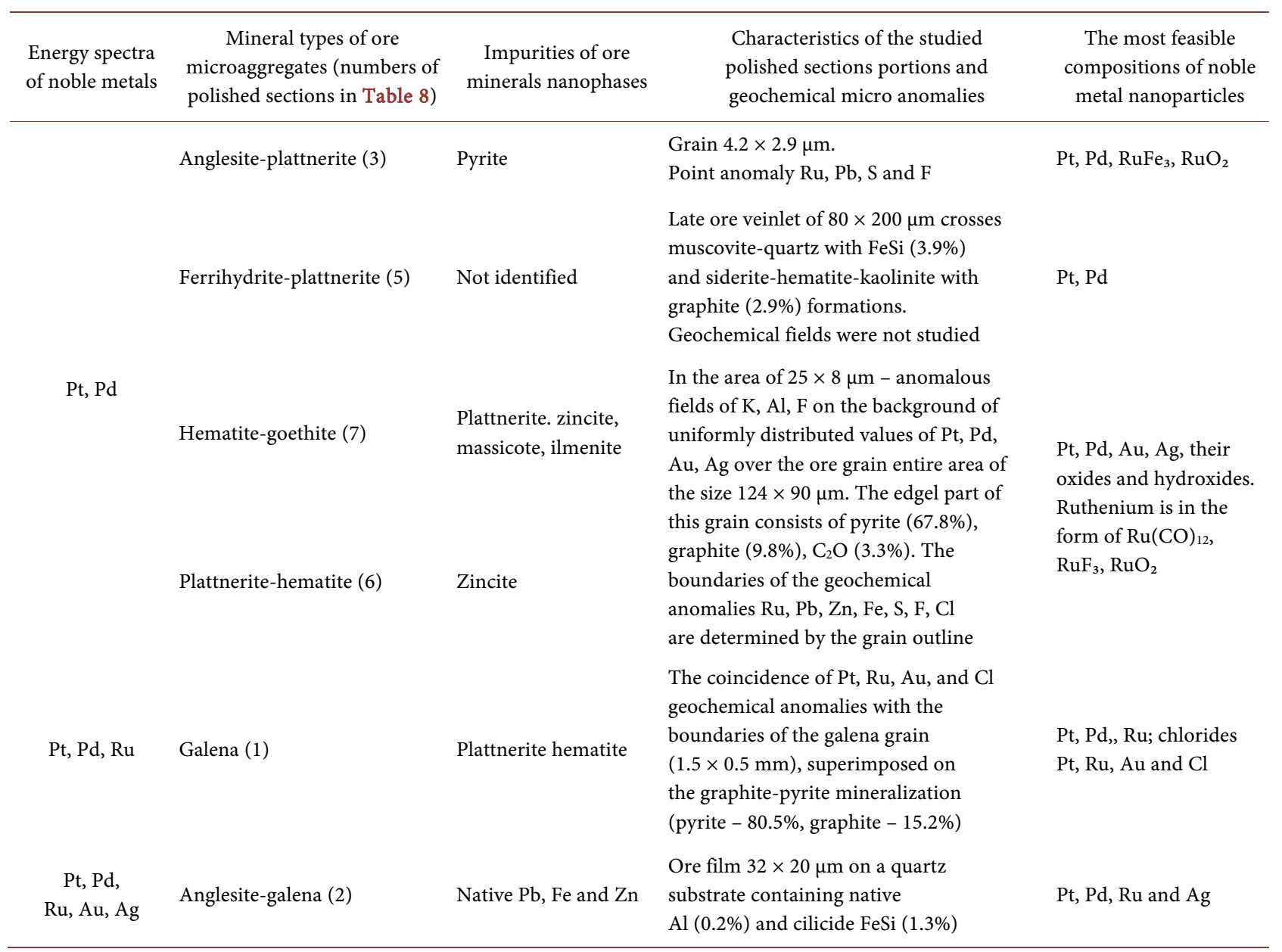




\section{Continued}

\begin{tabular}{|c|c|c|c|c|}
\hline $\mathrm{Pt}, \mathrm{Ru}, \mathrm{Au}, \mathrm{Ag}$ & $\begin{array}{l}\text { Manganite-plattnerite } \\
\text { (Point 4, on Figure 5) }\end{array}$ & $\begin{array}{l}\text { Manganosite, } \\
\text { zincite, goethite }\end{array}$ & $\begin{array}{l}\text { Ore film } 20 \times 12 \mu \mathrm{m} \text { on a } \\
\text { quartz-muscovite carbonaceous substrate. } \\
\mathrm{Ru}, \mathrm{Mn}, \mathrm{Zn} \text { and } \mathrm{S} \text { anomalies } \\
\text { coincide with it boundaries }\end{array}$ & $\begin{array}{l}\mathrm{Pt}, \mathrm{Ru}, \mathrm{Au}, \mathrm{Ag} \text { and } \\
\text { their oxides, sulphates } \\
\text { of } \mathrm{Ag}_{2} \mathrm{SO}_{4} \text { type }\end{array}$ \\
\hline
\end{tabular}

Table 10. Carbonyl genesis mineralogic and geochemical signs of noble metals ore nanominerals.

\begin{tabular}{ll}
\hline $\begin{array}{l}\text { Poly-elemental geochemical microfields } \\
\text { of carbonyl type }\end{array}$ & $\begin{array}{l}\text { Characteristic micro- and nanominerals and chemical compounds appeared from the } \\
\text { decay of the carbonyls and their derivatives as a result of dynamometamorphism }\end{array}$ \\
\hline $\mathrm{Pb}-\mathrm{Zn}-\mathrm{Mn}-\mathrm{Ru}-\mathrm{Pd}-\mathrm{Pt}-\mathrm{Au}-\mathrm{Ag}-\mathrm{C}-\mathrm{Cl}-\mathrm{F}$ & Native $\mathrm{Fe}, \mathrm{Pb}, \mathrm{Zn}, \mathrm{Al}$, silicide FeSi, moissanite, \\
$\mathrm{Pb}-\mathrm{Fe}-\mathrm{Ru}-\mathrm{S}-\mathrm{F}$ & $\begin{array}{l}\text { graphite, iocite, hematite, goethite, manganosite, } \\
\text { zincite, plattnerite, massicot, ferrihydrite, }\end{array}$ \\
$\mathrm{Pb}-\mathrm{Pd}-\mathrm{Pt}-\mathrm{O}-\mathrm{C}$ & $\begin{array}{l}\text { portlandite, calicinite, nahcolite, losiite, carobiite, } \\
\text { williamite, silica gel } \mathrm{SiO}_{2} \cdot \mathrm{nH}_{2} \mathrm{O}, \text { gelgraphite }\end{array}$ \\
$\mathrm{Zn}-\mathrm{Ru}-\mathrm{Au}-\mathrm{Ag}-\mathrm{S}-\mathrm{Cl}$ & $\mathrm{C} \cdot \mathrm{nH}_{2} \mathrm{O}$, oxides $\mathrm{C}_{2} \mathrm{O}_{3}, \mathrm{C}_{2} \mathrm{O}$ \\
&
\end{tabular}

Note: the structure of geochemical microfields is similar to the surfaces structures of carbonyl nickel coatings obtained at a substrate temperature of $500^{\circ} \mathrm{C}$, and is very similar to the discrete distribution pattern of nanoparticles in carbonyl metal powders W and Mo [Syrkin, Babin, 1986], mechanochemically synthesized powders (hematite + Fe-Al intermetallid) [Lyakhov et al., 2005], hydroxylapatite [Petrakova et al., 2018].

Table 11. The formation and evolution sequence of the ore-forming system (OFS), the main factors of ore substance mobilization and.

\begin{tabular}{|c|c|c|}
\hline OFS formation stages (time intervals) & $\begin{array}{l}\text { Sources of fluids and } \\
\text { ore components }\end{array}$ & $\begin{array}{l}\text { Mobilization and concentration } \\
\text { factors of ore elements }\end{array}$ \\
\hline Ore preparative I-magmatic (Riphean-Vend) & Mantle & $\begin{array}{l}\text { Fluid-magmatic. Ore-geochemical specialization of the } \\
\text { volcano-plutonic ultrabasite-basite association }\end{array}$ \\
\hline Ore preparative II-mud-volcanic (Cambrian) & Crustal & $\begin{array}{l}\text { Hydrothermal-sedimentary with the participation of } \\
\text { microorganisms during thermal sources functioning and the } \\
\text { formation of travertines ("limestone", "calcareous siltstones"). }\end{array}$ \\
\hline $\begin{array}{l}\text { Ore preparative III-dynamometamorphic } \\
\text { (medium? Paleozoic) }\end{array}$ & Crustal & $\begin{array}{l}\text { Tectonic-metamorphic. Inheritance with amphibolites, } \\
\text { crystalloslates and, serpentinites of ore-geochemical } \\
\text { specialization of the ore preparative rocks stages I and II. }\end{array}$ \\
\hline
\end{tabular}

Break. The granitoids formation of the Angara-Vitim areal-Pluton (upper Paleozoic)

Ore preparative IV-magmatic (lower Mesozoic)

Ore stages I-IV—dynamometamorphic (Triassic)

OFS biogenic transformation (Yurassic?-Cenozoic)
Mantle-crustal

Crustal

Crustal
Fluid-magmatic volcano-plutonic shoshonite-latite association, inherited ore-geochemical specialization of ore preparative stages I-III.

Tectonic-metamorphic. Deformational transformations of volcano-plutonic shoshonite-latite series rocks.

Biogenic inheritance of ore stages geochemical specialization with partial conservation of noble metal high concentrations.

of rock and ore minerals transformation, not containing any organic substances. This conclusion is confirmed by the experiments results [26] on mechanochemical synthesis from inorganic minerals (magnetite, siderite, quartz, calcite, pyrite)-hydrocarbons, which include $\mathrm{N}_{2}, \mathrm{CO}_{2}, \mathrm{H}_{2}, \mathrm{O}_{2}$.

Ore substance source. From the submitted above sections it follows that the 
leading element of Mykert-Sanzheevka field polycomponent ores is a lead. The overwhelming number of detected ore minerals appeared as a result of galena multiple deformational transformations. Lead in the form of plattnerite basically determines the ore mineralization productivity on the platinum-group metals. Therefore, knowing the sources of lead, we can judge about the sources of the most ore elements associating with it. Using the $\mathrm{Pb}$-isotope galena characteristics (Table 12) we will determine the source of lead and respectively paragenic with it ore elements.

For this purpose, from carefully selected galenas of lead-silver ores four representative samples of the North Sanzheevka site for isotope analysis, lead was separated by the method [27]. The $\mathrm{Pb}$ isotope analysis was performed on the multichannel mass spectrometer Finnigam MAT-261, belonging to the Irkutsk center of collective use, in the simultaneous registration mode of different isotopes ion currents. The fractionation factor was established by multiple measurements of the NBS-SRM-982 isotope standard. According to the obtained $\mathrm{Pb}$ isotope composition data (Table 12) on two-stage model [28] the model age datings were obtained determining the time of lead separation from the source, if after that leads isotopic compositions were not changed as a result of mixing with variable amounts of radiogenic lead. And also this model is not applicable to those leads, which were consequently in rock systems with different ratios of $\mathrm{U} / \mathrm{Pb}$ and $\mathrm{TH} / \mathrm{Pb}$.

The age limit for four samples was 558 - 649 million years, with values of $\left.\mu{ }^{238} \mathrm{U} /{ }^{204} \mathrm{~Pb}\right)$ in the range of $8.8-9.1$. The obtained value of $\mu$ is slightly lower than that of the Stacy-Kramers model (9.735), which indicates the involvement of a substance originating from the lower crust.

The obtained data indicate that the ore substabce primary sources of the Mykert-Sanzheevka OFS are mantle-crustal rock complexes of the earth crust lower part, composing the Vend-Riphean Greenstone belt (Selenga-Vitim South-West ending [5].

OFS evolution had an inherited multistage nature, with a tendency to be changed in time of ore-generating and ore-concentrating processes.

The uniqueness of Mykert-Sanzheevka OFS is that, that in the final stage of its evolutionary development, it goes into the biogenic regeneration phase, characterized by the change of the mobilization rock forms and ore substance concentration-biological (woody vegetation, microorganisms) [29].

Table 12. Pb-isotope galenas data of North Sanzheevka site.

\begin{tabular}{ccccccc}
\hline No. & Sample & $206 / 204$ & $207 / 204$ & $208 / 204$ & $\mathrm{~T}(\mathrm{~m}$. years $)$ & ${ }^{238} \mathrm{U} /{ }^{204} \mathrm{~Pb}$ \\
\hline 1 & K-2012 & 17.222 & 15.344 & 37.217 & 556 & 8.86 \\
2 & 4062 & 17.243 & 15.389 & 37.368 & 633 & 9.06 \\
3 & 4081 & 17.263 & 15.404 & 37.417 & 648 & 9.13 \\
4 & 4071 & 17.243 & 15.383 & 37.349 & 621 & 9.03 \\
\hline
\end{tabular}

Note: The analyses were obtained using the method of La-ISP-MS V.F. Posokhov (GIN SO PAS). 


\section{Conclusions}

The main implemented new research results of polycomponent noble-metalpolymetallic mineralization of Mykert-Sanzheevka ore field are:

- Its geological structure is specified to belong to the charriage thrust tectonic type presented by the ore-controlling losange consisting of rhombohedral and tetrahedral blocks-duplexes set, separated by narrow tectonic sutures made by ore dynamometamorphites;

- A number of ore-bearing rocks petrochemical types of shoshonite-latite volcano-plutonic association is selected, mainly consisting of dyke series (tefroite, trachybasalt, trachyandesite-basalt) and syenite rocks;

- Dynamometamorphic ore-bearing complex of rocks is divided into breccias, cataclasite, mylonites and mechanometasomatites of two varieties (micaceous-carbonate-quartz and argillite). The crushed-debris tectonites are referred to kakirites group;

- Deformational (mechanochemical) mineral new formations in rock-forming, secondary, and also accessory ore minerals of the primary rocks subjected to dynamometamorphism are revealed;

- 4 short-term stages of dynamometamorphites formation, characterized by the various associations formation of ore minerals are selected;

- A carbonyl model of the mineral microaggregates formation with films containing MPG nanoparticles, less often $\mathrm{Ag}$ and $\mathrm{Au}$, is proposed;

- The most feasible mineral occurrence forms in ores of noble metals nanophases are identified;

- The age of $233 \pm 19$ million years of the ore-rock dynamometamorphic complex was determined by the isotope-geochemical Rb-Sr method;

- The evolutionary model of the Mykert-Sanzheevka field ore-forming system is proposed.

\section{Conflicts of Interest}

The authors declare no conflicts of interest regarding the publication of this paper.

\section{References}

[1] Mironov, A.G., Tatarinov, A.V., Damdinov, B.B., Kovalevskaya, O.M., Yalovik, L.I. and Kolesov, G.M. (2004) New Types of Platinum-Ruthenium Mineralization in Silver-Polymetallic Ores. Academy of Sciences Reports, 395, 231-235.

[2] Mironov, A.G., Zhmodik, S.M., Kolesov, G.M., Mitkin, V.N., Damdinov, B.B. and Zayakina, S.B. (2008) Platinum Group Elements in Gold-Sulfide and Base-Metal Ores of the Sayan-Baikal Fold Region and Possible Platinum and Palladium Speciation in Sulfides. Geology of Ore Deposits, 50, 41-59. https://doi.org/10.1134/S1075701508010029

[3] Tatarinov, A.V., Yalovik, L.I., Kolesov, G.M., Kanakin, S.V. and Prokopchuk, S.I. (2011) Platinum Group Elements in the Super-Ore Series of the Baleiskoe Ore Field. Doklady Earth Sciences, 436, 47-50. 
https://doi.org/10.1134/S1028334X10901131

[4] Tatarinov, A.V., Yalovik, L.I. and Posokhov, V.F. (2014) Formation Peculiarities of the Noble Metals Irba Deposit (West Transbaikalia). Geology and Mineral Resources of Siberia, 3, 117-119.

[5] Tatarinov, A.V., Yalovik, L.I. and Batyshev, V.G. (2014) Noble-Metal Ore-Forming System of the Vendian-Riphean Selenga-Vitim Greenstone Belt. Domestic Geology, 3, 17-25.

[6] Tatarinov, A.V., Yalovik, L.I. and Vanin, V.A. (2016) Spherical Microparticles from Gold-Bearing Quartz Veins of the Irokinda Deposit, Western Transbaikalia. Geodynamics and Tectonophysics, 7, 651-662. https://doi.org/10.5800/GT-2016-7-4-0226

[7] Kovalevsky, A.L., Kovalevskaya, O.M. and Prokopchuk, S.I. (1993) On the Use of Scintillation Emission Spectral Analysis in Biogeochemical Searches of Platinoids. Geology and Geophysics, 4, 101-111.

[8] Kovalevsky, A.L., Kovalevskaya, O.M., Tatyankina, E.M. and Prokopchuk, S.I. (1998) Features of Platinum and Palladium Biogeochemical Migration in the Landscapes of the Transbaikalia Southern Taiga. Academy of Sciences Reports, 358, 248-251.

[9] Feklichev, V.G. (1977) Diagnostic Spectra of Minerals. Nedra, Moscow, 228.

[10] Vorontsov, A.A., Yarmolyuk, V.V., Kovalenko, V.I., Lykhin, D.A., Dril, S.I., Tatarnikov, S.A. and Sandomirova, G.P. (2005) Magmatism and Geodynamic Reconstruction of the North-Mongolia-West Transbaikalia Rift Zone in late Triassic-Early Jurassic. Problems of Deep Magmatism and Plume Sources. Proceedings of VIntern Seminar's, Irkutskm Petropavlovsk-Kamchatsky, 2, 50-79.

[11] Zorina, L.D. (1987) Ore-Magmatic Systems of Transbaikalia with Latite Magmatism. Current Problems of Theoretical and Applied Geochemistry. Science, Siberian Branch, Novosibirsk, 93-100.

[12] Spiridonov, A.M., Zorina, L.D. and Kitaev, N.A. (2006) Auriferous Ore-Magmatic Systems of Transbaikalia. GEO, Novosibirsk, 291.

[13] Tauson, L.V. (1977) Geochemical Types and Potential Ore-Bearness of Granitoids. Science, Moscow, 280.

[14] (1994) Diagnostics and Mapping of Scaly-Thrust Structures. Methodical Manual, Roskomnedra VSEGEI, Saint-Petersburg, 191.

[15] Tatarinov, A.V., Yalovik, L.I. and Yalovik, G.A. (2004) Gold Mineralization in Thrust Structures of the Mongol-Okhotsk Collisional Suture (Pre-Shilka and Onon-Turin Zones). Pacific Geology, 23, 22-31.

[16] Tsechovsky, Y.G., Scherbakova, T.F., Nikitin, A.V., Simanovich, I.M. and Poleshchuk, A.V. (2011) Tectonic Disintegration and Rocks Silicification in Granitoids Protrusion of the Massif Tobhor (West Transbaikalia). Society of Naturalists Bulletin, 86, 7-18.

[17] Chikov, B.M. (2011) Introduction to the Physical Basis of Static and Dynamic Geotectonics. GEO, Novosibirsk, 299.

[18] Matvienko, V.N., Kalashnikov, Yu.D. and Narseev, V.A. (2004) Clusters-The Occurrence Proto-Form of Precious Metals in Ores and Mineralized Rocks. Ores and Metals, 5, 28-36.

[19] Semyonov, I.N. and Ovchinnikov, K.V. (1972) "Unexpected" Inorganic Compounds. Chemistry, Moscow, 12.

[20] Syrkin, V.G. and Babin, V.N. (1986) Gas grows Metals. Science, Moscow, 190. 
[21] Rudashevsky, N.S. and Simakov, S.K. (1986) On Mobilization of Platinum in Platinum-Bearing Rocks (on the Example of Aldan Shield Central Type Dunite Massifs). USSR Academy of Sciences Reports, 288, 972-976.

[22] Buslayeva, E.Yu. and Novgorodova, M.I. (1989) Organoelement Compounds in the Problem of Ore Substance Migration. Science, Moscow, 152.

[23] Even, J., Yakushev, A., Dullmann, C.E., Dvorak, J., Eichler, R., Gothe, O., Hartmann, W., Hild, D., Jager, E., Khuyagbaatar, J., Kindler, B., Kratz, J.V., Krier, J., Lommel, B., Niewisch, L., Nitsche, H., Pysmenetska, I., Schadel, M., Schausten, B., Turler, A., Wiehl, N. and Wittwer, D. (2014) In-Situ Formation, Thermal Decomposition, and Adsorption Studies of Transition Metal Carbonyl Complexes with Short-Lived Radioisotopes. Radiochimica Acta, 102, 1093-1110.

[24] Lyakhov, N.Z., Vityaz, P.A., Grigorieva, T.F., Talako, T.L., Barinova, A.P. and Letsko, A.I. (2005) Mechanochemically Synthesized Precursors for the Preparation of Intermetallic Compound/Oxide Nanocomposites by SHS. Doklady Chemistry, 405, 225-257. https://doi.org/10.1007/s10631-005-0085-3

[25] Petrakova, N.V., Bakunov, V.S., Barinov, S.M. and Titov, D.D. (2018) Features of the Kinetics of Sintering of Hydroxyapatite Powders with Various Particle Sizes. Doklady Chemistry, 483, 308-311. https://doi.org/10.1134/S0012500818120029

[26] Chersky, N.V. and Tsarev, V.P. (1984) Mechanism of Hydrocarbons Synthesis from Inorganic Compounds in the Upper Crust Horizons. USSR Academy of Sciences Reports, 279, 730-735.

[27] Krogh, T.E. (1973) A Low-Contamination Method for Hydrothermal Decomposition of Zircon and Extraction of $\mathrm{U}$ and $\mathrm{Pb}$ for Isotopic Age Determination. Geochimica et Cosmochimica Acta, 37, 485-494. https://doi.org/10.1016/0016-7037(73)90213-5

[28] Stacey, J.S. and Kramers, V.D. (1975) Approximation of Terrestrial Lead Isotope Evolution by a Two-Stage Model. Earth and Planetary Science Letters, 26, 207-221. https://doi.org/10.1016/0012-821X(75)90088-6

[29] Tatarinov, A.V., Yalovik, L.I., Danilova, E.V., Prokopchuk, S.I. and Zhmodik, S.M. (2007) The Role of Microorganisms in the Hypergenic Transformation of Polymetallic Ores and the Formation of Noble Metals Biogeochemical Anomalies in the Transbaikalia Fields. Academy of Sciences Reports, 414, 651-655. 